\title{
Multiple Renal Arteries in Kidney Transplantation: Is it a Problem Nowadays?
}

\section{Artérias Renais Múltiplas na Transplantação Renal: Será um Problema Actualmente?}

\author{
João Carvalho*, Pedro Nunes, Belmiro Parada, Edgar Tavares-da-Silva, Hugo Antunes, António Roseiro, Carlos Ferreira, \\ Arnaldo Figueiredo
}

\section{Abstract}

Introduction: Shortage of high quality donors led to an increasing need of compatible organs: grafts with multiple renal arteries (MRA) are one of the solutions, although being a potential risk factor that can impair outcomes. The aim of this study is to provide a view of our experience with multiple renal arteries grafts in renal transplantation and compare the outcome between multiple renal arteries and single renal artery (SRA) groups.

Material and Methods: A retrospective study of 2989 kidney transplants was performed in our department between January 1980 and February 2017: demographic characteristics and outcomes were compared between recipients of grafts with multiple renal arteries $(648 ; 21.7 \%)$ and single renal artery (2341; 78.3\%). Statistical analysis was done using IBM SPSS Statistics 22: chi-square, independent sample t-test and Kaplan Meier tests were used with a p value of 0.05 .

Results: Grafts from cadaveric donors occurred in $95.8 \%$ of the single renal artery group and $97.4 \%$ of multiple renal arteries group. The recipients of multiple renal arteries group had a previous higher time on dialysis $(50.3 \pm 43.1$ vs $46.30 \pm 37.5$ months, p:0.04), a longer operative time (2.43 \pm 0.57 vs 2.28 \pm 0.49 hours, $p<0.001)$, a higher cold ischemia time (19h08 \pm 6 h05 vs $18 h 34 \pm 6 h 17$ hours, p:0.04) and more red blood cell transfusions (1.8 \pm 0.8 vs $1.7 \pm 0.8$ packs, p:0.01) than the recipients of single renal artery kidney recipients. In the multiple renal arteries group, ex-vivo bench surgery techniques, in vivo sequential anastomosis and mixed techniques were used. The different options did not affect the outcomes. The rate of delayed graft function, surgical complications, length of hospital stay, acute and chronic rejections, graft loss, death were not statistically different. The follow-up was not statistically different: multiple renal arteries ( $8 \pm 7.3$ years) versus single renal artery $(7.7 \pm 6.6$ years) group (p:0.1). The current state of the patient was not dependent on the number of arteries used.

\section{Resumo}

Introdução: A escassez de dadores leva a uma necessidade crescente de órgãos compatíveis: enxertos com múltiplas artérias renais (do inglês multiple renal arteries - MRA) são uma das soluções, apesar de ser um fator de risco potencial que pode prejudicar os resultados. O objetivo deste estudo é avaliar os nossos resultados com enxertos com múltiplas artérias renais e compará-los com enxertos com artéria renal única (do inglês single renal artery - SRA).

Material e Métodos: Foi realizado um estudo retrospectivo de 2989 transplantes renais realizados na nossa instituição entre janeiro de 1980 e fevereiro de 2017: características demográficas e os resultados foram comparados entre receptores de enxertos com múltiplas artérias renais $(648 ; 21,7 \%)$ e artéria renal única (2341; 78,3\%). A análise estatística foi efectuada recorrendo ao SPSS Statistics 22: teste qui-quadrado, teste t para amostras independentes e teste de Kaplan-Meier com um valor de p de 0,05. Resultados: Foram utilizados enxertos de dadores cadáver em 95,8\% do grupo artéria renal única e 97,4\% do grupo múltiplas artérias renais. Os receptores do grupo múltiplas artérias renais estiveram mais tempo em diálise $(50,3 \pm 43,1$ vs 46,30 $\pm 37,5$ meses, $p$ : 0,04), um tempo cirúrgico maior $(2,43 \pm 0,57$ vs 2,28 $\pm 0,49$ horas, $p<0,001$ ), maior tempo de isquémia fria $(19 h 08 \pm 6 h 05$ vs $18 h 34 \pm 6 h 17$ horas, $p: 0,04)$ e necessitaram de mais transfusões de glóbulos vermelhos $(1,8 \pm 0,8$ vs 1,7 $\pm 0,8$ Unidades, $p: 0,01$ ) do que os receptores de receptores do grupo artéria renal única. No grupo múltiplas artérias renais, foram utilizadas técnicas de cirurgia de banca ex-vivo, anastomose sequencial in vivo e técnicas mistas. As diferentes opções não tiveram influência nos resultados. A taxa de função tardia do enxerto, complicações cirúrgicas, tempo de internamento, rejeições agudas e crónicas, perda do enxerto e morte não foram estatisticamente diferentes. O seguimento não foi estatisticamente diferente: grupo múltiplas artérias renais ( $8 \pm 7,3$ anos) versus artéria renal única (7,7 $\pm 6,6$ anos) $(p: 0,1)$. O estado actual do doente não dependia do número de artérias utilizadas. 
Conclusion: Multiple renal arteries grafts were not a problem in our unit: despite of having a longer operative time, higher cold ischemia time and higher blood transfusions rate, short and long-term outcomes were comparable between groups. At this level, literature results are not consensual: prospective studies are necessary.

Keywords: Kidney Transplantation; Renal Artery/abnormalities.

\section{Introduction}

Renal transplantation is considered the preferred treatment in patients with end-stage renal disease, improving the quality of life and survival. ${ }^{1}$ Shortage of high quality donors for an increasing rate of end-stage renal disease patients led to an increasing need of compatible organs. Thus, kidneys with anatomical abnormalities, such as multiple renal arteries, multiple ureters, paediatric kidneys and horseshoe kidneys began to be progressively used despite being considered as risk factors for urologic and vascular complications. The most common anatomical anomaly is arterial multiplicity and represents a tricky challenge in the operating room. Novick et a ${ }^{2}$ showed an incidence of $23 \%$ for multiple donor unilateral renal arteries and $10 \%$ for multiple bilateral renal arteries. These organs represent a useful opportunity for many recipients. However, the risk of complications also increases with the use of such grafts: longer period of ischemia, higher rate of late graft function and worse prognosis. Surprisingly, the literature reports an excellent prognosis with that vascular multiplicity. ${ }^{3-4}$

The aim of this work is to evaluate our experience with multiple renal artery (MRA) grafts and to compare the prognosis between renal transplants with MRA with single renal artery (SRA) grafts.

\section{Material and Methods}

A retrospective observational study was performed in our center (Urology and Renal Transplantation Department, Coimbra University Hospital Center) and included 2989 recipients who underwent renal transplantation in our hospital, between January 1980 and February 2017.

Two groups were created: 648 patients $(21.7 \%)$ received MRA grafts and 2341 patients (78.3\%) received SRA grafts. In the group of MRA grafts, 85.6 had 2 arteries, $12.8 \%$ had 3 arteries and $1.6 \%$ had 4 arteries.

The age effect and donors and recipients gender effects on prognosis were evaluated. Several variables were compared between groups: type of donor, previous length on dialysis, surgery duration, cold ischemia time, number of red blood
Conclusão: Apesar do maior tempo cirúrgico, maior tempo de isquemia fria e maior taxa de transfusões de glóbulos vermeIhos, os resultados do nosso centro no transplante de rins com múltiplas artérias renais foram idênticos aos de rins com artéria renal única no que diz respeito à função, sobrevida e taxas de complicações cirúrgicas. A este nível os resultados da literatura não são consensuais, sendo necessários estudos prospectivos.

Palavras-chave: Artéria Renal/anomalias congénitas; Transplante Renal. cell packs transfused, renal function over time, using serum creatinine and glomerular filtration rate (GFR; using the Cockcroft-Gault equation). Delayed graft function, surgical complications, hospital length of stay, acute and chronic rejection, follow-up, death and its cause were also evaluated. Type of anastomosis chosen in the MRA grafts was also evaluated. Data were evaluated anonymously.

Statistical analysis was performed using IBM SPSS Statistics 20.0 software for Windows (Statistical Package for the Social Sciences, version 20.0, IBM Corp., USA). Categorical variables were compared using the Pearson chi-square nonparametric test and the quantitative variables were compared using the independent t-student test and the ANOVA test. Overall patient and graft survival analysis was performed using the Kaplan Meyer method and the log-rank test. These tests were considered statistically significant with a $p$-value of less than 0.05 .

\section{Results}

Donor and recipient characteristics of both groups are shown in Table 1. The majority of donors were deceased in each group: one important fact is that only 17 living donors' grafts had MRA and no association was seen between the number of renal arteries and donor type. The majority of donors were male in both groups. Both donor age, ventilation time and diuresis at the last hour were nearly the same between groups.

Recipients' demographic characteristics were also similar. Only pretransplantation dialysis time was higher in MRA grafts group ( $50.3 \pm 43.1$ vs $46.3 \pm 37.5$ months, $p$ : 0.04$)$.

Perioperative data are summarized in Table 2: a slightly higher, but statistically significant, cold ischemia period, longer surgery duration and a higher need for red blood cell transfusion was noticed in MRA grafts transplantation.

Immunosuppression protocols did not differ between groups. The single renal artery was anastomosed to aorta in $0.5 \%$, to the common iliac artery in $73.9 \%$, to the external iliac artery in $23.3 \%$, to the internal iliac artery in $2.1 \%$ and to the opposite common iliac artery in $0.2 \%$. The single renal artery 
Table 1: Donor and recipients data with SRA (single renal artery) versus MRA (multiple renal artery) grafts

\begin{tabular}{|c|c|c|c|}
\hline Deceased donor & $2242(95.8 \%)$ & $631(97.4 \%)$ & NS $(p: 0.06)$ \\
\hline Living donor & $99(4.2 \%)$ & $17(2.6 \%)$ & \\
\hline $\begin{array}{l}\text { Donor gender } \\
0^{7} \\
\text { ㅇ }\end{array}$ & $\begin{array}{c}1568(67 \%) \\
773(33 \%)\end{array}$ & $\begin{array}{l}461(71.2 \%) \\
187(28.8 \%)\end{array}$ & $\mathrm{S}(p: 0.04)$ \\
\hline Mean donor age (years) & $41.9 \pm 17.1$ & $41.9 \pm 17.6$ & NS $(p: 0.9)$ \\
\hline Donor ventilation time (hours) & $55.7 \pm 61.9$ & $59.1 \pm 65.0$ & NS $(p: 0.2)$ \\
\hline Donor diuresis per hour (mL) & $231.8 \pm 273.3$ & $233.3 \pm 248.7$ & NS $(p: 0.9)$ \\
\hline Recipient age & $45.1 \pm 14.1$ & $45.6 \pm 13.5$ & NS $(p: 0.4)$ \\
\hline Pretransplantation dialysis time (months) & $46.3 \pm 37.5$ & $50.3 \pm 43.1$ & $\mathrm{~S}(p: 0.04)$ \\
\hline $\begin{array}{l}\text { Etiology of end-stage renal disease (\%) } \\
\text { Glomerular disease } \\
\text { Tubulointerstitial disease } \\
\text { Cystic congenital disease } \\
\text { Systemic disease } \\
\text { Undetermined or unknown }\end{array}$ & $\begin{array}{c}524(22.4 \%) \\
398(17 \%) \\
190(8.1 \%) \\
461(19.7 \%) \\
768(32.8 \%)\end{array}$ & $\begin{array}{c}161(24.9 \%) \\
97(15 \%) \\
57(8.8 \%) \\
123(18.8 \%) \\
210(32.5 \%)\end{array}$ & NS (0.6) \\
\hline
\end{tabular}

NS - not significant

Aza - azathioprine; THYMO - thymoglobulin; MY - mycophenolic acid; M - mycophenolate mofetil; P - prednisolone; CsA - cyclosporine; THYMO - thymoglobulin; FK - tacrolimus; SIR - sirolimus; EVRL - everolimus

was anastomosed whenever possible using an aortic donor patch (Carrel technique).

Multiple renal arteries were anastomosed to the aorta in $0.2 \%$, to the common iliac artery in $75 \%$, to the external iliac artery in $22.0 \%$, to the internal iliac artery in $2.4 \%$ and to the opposite common iliac artery in $0.3 \%$. The type of arterial anastomosis (Table 3) was sometimes different: ex-vivo bench surgery techniques, in vivo sequential anastomosis and mixed techniques. Ex-vivo bench surgery techniques included endto-side anastomosis, the use of cadaveric arterial grafts and the creation of a joined patch that could make the in vivo anastomosis easier. In vivo sequential anastomosis included anastomosis of the multiple renal arteries to one or more recipient arteries. Mixed techniques included both bench and 
Table 2: Perioperative data of recipients of SRA and MRA grafts

\begin{tabular}{|c|c|c|c|}
\hline Perioperative Data & SRA grafts & MRA grafts & $p$ value \\
\hline $\begin{array}{l}\text { Kidney Used } \\
\text { Left } \\
\text { Right }\end{array}$ & $\begin{array}{l}1180(50.4 \%) \\
1161(49.6 \%)\end{array}$ & $\begin{array}{l}330(51.0 \%) \\
318(49.0 \%)\end{array}$ & NS $(p: 0.8)$ \\
\hline $\begin{array}{l}\text { Renal graft placement side } \\
\text { Left } \\
\text { Right }\end{array}$ & $\begin{array}{c}407(17.4 \%) \\
1934(82.6 \%)\end{array}$ & $\begin{array}{l}126(19.5 \%) \\
522(80.5 \%)\end{array}$ & NS (p:0.2) \\
\hline Cold ischaemia duration (hh:mm) & $18: 34 \pm 6: 17$ & $19: 08 \pm 6: 05$ & $S(p: 0.04)$ \\
\hline $\begin{array}{l}\text { CVP on vessel dislodging } \\
\left(\mathrm{CmH}_{2} \mathrm{O}\right)\end{array}$ & $12.9 \pm 3.5$ & $12.7 \pm 3.5$ & NS $(p: 0.2)$ \\
\hline $\begin{array}{l}\text { Systolic blood pressure in } \\
\text { reperfusion }(\mathrm{mmHg})\end{array}$ & $125.4 \pm 19.5$ & $124.8 \pm 20.3$ & NS $(p: 0.6)$ \\
\hline $\begin{array}{l}\text { Diastolic blood pressure in } \\
\text { reperfusion }(\mathrm{mmHg})\end{array}$ & $73.8 \pm 13.6$ & $73.6 \pm 14.0$ & NS $(p: 0.8)$ \\
\hline $\begin{array}{l}\text { Surgery Duration } \\
\leq 3 \text { hours } \\
>3 \text { hours }\end{array}$ & $\begin{array}{l}1959(83.7 \%) \\
382(16.3 \%)\end{array}$ & $\begin{array}{l}479(74.0 \%) \\
169(26.0 \%)\end{array}$ & $S(p<0.001)$ \\
\hline Surgery duration (hh:mm) & $2: 28 \pm 0: 49$ & $2: 43 \pm 0: 57$ & $S(p<0.001)$ \\
\hline $\begin{array}{l}\text { Initial graft function } \\
\text { Never-functioning kidney } \\
\text { Initial diuresis } \\
\text { DGF }\end{array}$ & $\begin{array}{c}103(4.4 \%) \\
1840(78.6 \%) \\
398(17.0 \%)\end{array}$ & $\begin{array}{c}30(4.6 \%) \\
516(79.7 \%) \\
102(15.7 \%)\end{array}$ & NS $(p: 0.7)$ \\
\hline Red blood cell transfusion (Units) & $1.6 \pm 0.9$ & $1.8 \pm 0.9$ & $\mathrm{~S}(p: 0.01)$ \\
\hline Hospital length of stay (days) & $12.0 \pm 0.8$ & $12.0 \pm 118.4$ & NS $(p: 0.3)$ \\
\hline
\end{tabular}

sequential anastomosis. There was no statistically significant relationship between the number of arteries and the type of arterial anastomosis $(p=0.5)$.

Surgical complication rate was independent of the number of graft renal arteries ( $p$ : 0.4), as shown in Table 4. The number of graft renal arteries was also not important for the number of clinical and biopsied acute rejections, for the development of chronic graft nephropathy and for graft loss. There was also no association between the death cause and the number of graft renal arteries (Table 5).

Renal function was assessed by measuring serum creatinine level and by calculation of clearance using the Cockcroft-Gault formula: both did not differ significantly between groups (Table 6).

Renal graft survival was identical [MRA group $(6.6 \pm 6.7$ years) versus SRA group (8.0 \pm 3.2 years $), p$ : 0.5$]$ as well as the overall follow-up [MRA group $(8 \pm 7.3$ years $)$ versus SRA $(7.7 \pm 6.6$ years), p: 0.1] (Fig. 1). Graft survival was not statiscally different at the first year after transplantation, (SRA - 93\% vs MRA - 90\%, p: 0.2), at the fifth year (88\% vs 88\%, p: 0.4 ), and at tenth year ( 86 vs $85 \%, p: 0.5$ ). The current state of the patient (alive, dead or on dialysis) was not dependent on the number of renal arteries.

The different types of arterial anastomosis did not have any impact in the graft survival ( $p$ : 0.07) (Table 7).

\section{Discussion}

This study shows that kidney transplantation in Urology and Renal Transplantation Department with multiple renal arteries is a safe procedure with good results either in an early or in a late phase. Only an experienced team with good protocols could have these results: our center has performed 2989 kidney transplants since 1980, with high skills developed through the time. Procurement technique is essential to identify all MRA in grafts in order to have viable grafts for the recipients. Our series showed a prevalence of $21.7 \%(n=648)$ : this is a high number for only one center but it is similar to other centers numbers. Typically, MRA is observed in $8 \%$ to $30 \%$ of donors. ${ }^{5}$

A recent meta-analysis ${ }^{6}$ shows that kidney grafts with MRA were associated with higher rate of complications such as delayed graft function, vascular and urological complications. Our data showed no difference: the vascular screening of re- 
Table 3: Relationship between the number of renal arteries and the type of arterial anastomosis

\begin{tabular}{|l|c|c|c|c|}
\hline \multirow{2}{*}{ Type of arterial anastomosis } & \multicolumn{3}{|c|}{ Number of renal arteries } & \\
Ex-vivo bench surgery techniques & $\mathbf{2}$ & $\mathbf{3}$ & $\mathbf{4}$ \\
\hline In vivo sequential anastomosis & $403(62.2)$ & $55(8.5)$ & $7(1.1 \%)$ \\
\hline Mixed techniques & $139(21.4 \%)$ & $25(4.0 \%)$ & $4(0.6 \%)$ \\
\hline Total & $11(1.7 \%)$ & $4(0.6 \%)$ & $168(25.9 \%)$ \\
\hline
\end{tabular}

Table 4: Surgical complications on recipients of SRA and MRA grafts

\begin{tabular}{|c|c|c|c|c|}
\hline \multirow{2}{*}{ Surgical complications } & \multicolumn{2}{|c|}{ Number of renal arteries } & \multirow{2}{*}{ Total } & \multirow{2}{*}{$p$ value } \\
\hline & SRA & MRA & & \\
\hline Vascular & 105 & 29 & 134 & NS $(p: 0.5)$ \\
\hline Urological & 149 & 38 & 187 & NS $(p: 0.7)$ \\
\hline Lymphocele & 36 & 8 & 44 & NS (p:0.7) \\
\hline Bleeding & 76 & 29 & 105 & NS (p:0.3) \\
\hline Wound dehiscence & 41 & 5 & 46 & NS $(p: 0.4)$ \\
\hline Surgical Site Infection & 8 & 3 & 11 & NS $(p: 0.8)$ \\
\hline Hernia & 9 & 3 & 12 & NS $(p: 0.9)$ \\
\hline Total & 424 & 115 & 539 & NS $(p: 0.4)$ \\
\hline
\end{tabular}

cipients at appointment maybe could explain our success in these fields. The majority of grafts independently of groups had an immediate initial diuresis. However, a higher cold ischaemia time was noticed with multiple renal arteries grafts but it was also lower compared with other series. ${ }^{5}$

Our MRA grafts took more time than SRA grafts but in the majority of cases with no more than three hours. One vies that was not evaluated separately was the time of arterial reconstruction that could have an important role: future studies must have this variable. Arterial reconstruction is one of the keys: the technique adopted was not different when we have more than one artery and didn't have repercussions in graft survival. The ex-vivo bench technique was considered the preferred technique. Arterial branches with a diameter larger than 0.5 $\mathrm{mm}$ should be preserved if possible. ${ }^{7}$ Our center mostly chose the ex-vivo bench technique: a single anastomosis is easier to performed with recipient's artery. If the distance between multiple arteries was large enough to prevent a safe reconstruction, a sequential or mixed anastomosis was chosen. When the donor is deceased, we use the aortic patch (of Carrel), technique that cannot be done with living donors.

Another bias of this study is being retrospective: future studies must have this variable into account.

Renal function was not different between groups during the time. In other series, 5,8 it was shown some differences during the time, especially in the first month.

Grafts survival was not influenced by having more than one artery during the time. MRA graft survival at 1 year was $90 \%$, at 5 years was $88 \%$ and at 10 years was $85 \%$. Typically, grafts survivals at 1 year varied from $82.8 \%$ to $96 \%$ and 
Table 5: Post-operative complications in recipients of SRA and MRA grafts

\begin{tabular}{|c|c|c|c|}
\hline \multirow{2}{*}{ Post-operative complications } & \multicolumn{2}{|c|}{ Number of renal arteries } & \multirow{2}{*}{ p value } \\
\hline & SRA & MRA & \\
\hline $\mathrm{cAR}$ & $1.1 \pm 0.4$ & $1.09 \pm 0.3$ & NS $(p: 0.4$ \\
\hline $\mathrm{bAR}$ & $1.1 \pm 0.6$ & $1.07 \pm 0.7$ & NS $(p: 0.8$ \\
\hline Chronic graft nephropathy & 456 & 131 & NS $(p: 0.5$ \\
\hline $\begin{array}{l}\text { Graft loss } \\
\text { Chronic Rejection } \\
\text { Vascular/Urological } \\
\text { Infectious } \\
\text { Renal Disease Relapse } \\
\text { Acute Rejection } \\
\text { Death with functioning graft } \\
\text { Lack of compliance } \\
\text { Never-functioning kidney }\end{array}$ & $\begin{array}{c}954 \\
401 \\
31 \\
32 \\
7 \\
16 \\
356 \\
15 \\
96\end{array}$ & $\begin{array}{c}277 \\
114 \\
10 \\
11 \\
0 \\
5 \\
107 \\
5 \\
25\end{array}$ & NS $(p: 0.6$ \\
\hline $\begin{array}{l}\text { Death cause } \\
\text { Cardiovascular } \\
\text { Infectious } \\
\text { Hepatic insufficiency } \\
\text { Neoplasia } \\
\text { Unknown }\end{array}$ & $\begin{array}{c}159 \\
134 \\
20 \\
64 \\
200\end{array}$ & $\begin{array}{c}45 \\
45 \\
7 \\
20 \\
54\end{array}$ & NS $(p: 0.9$ \\
\hline
\end{tabular}

SRA - single renal artery; MRA - multiple renal artery; cAR - clinical acute rejection; bAR - biopsied acute rejection; NS - not significant

Table 6: Creatinine serum value and clearance using the Cockcroft-Gault formula between groups

\begin{tabular}{|c|c|c|c|c|}
\hline \multirow{2}{*}{ Time } & \multirow{2}{*}{ Variables } & \multicolumn{2}{|c|}{ Number of renal arteries } & \multirow{2}{*}{$p$ value } \\
\hline & & SRA & MRA & \\
\hline 1 month & $\begin{array}{c}\mathrm{Cr}(\mathrm{mg} / \mathrm{dL}) \\
\operatorname{GFR}\left(\mathrm{mL} / \mathrm{min} / 1.73 \mathrm{~m}^{2}\right)\end{array}$ & $\begin{array}{c}1.6 \pm 1.0 \\
63.9 \pm 24.2\end{array}$ & $\begin{array}{c}1.6 \pm 1.1 \\
63.1 \pm 23.1\end{array}$ & $\begin{array}{l}\text { NS (p:0.9) } \\
\text { NS (p:0.4) }\end{array}$ \\
\hline 6 months & $\begin{array}{c}\mathrm{Cr}(\mathrm{mg} / \mathrm{dL}) \\
\operatorname{GFR}\left(\mathrm{mL} / \mathrm{min} / 1.73 \mathrm{~m}^{2}\right)\end{array}$ & $\begin{array}{l}1.6 \pm 3.5 \\
65.7 \pm 22.6\end{array}$ & $\begin{array}{c}1.4 \pm 0.5 \\
65.6 \pm 22.5\end{array}$ & $\begin{array}{l}\text { NS (p:0.4) } \\
\text { NS (p:0.9) }\end{array}$ \\
\hline 12 months & $\begin{array}{c}\mathrm{Cr}(\mathrm{mg} / \mathrm{dL}) \\
\operatorname{GFR}\left(\mathrm{mL} / \mathrm{min} / 1.73 \mathrm{~m}^{2}\right)\end{array}$ & $\begin{array}{c}1.4 \pm 0.6 \\
67.4 \pm 22.8\end{array}$ & $\begin{array}{c}1.4 \pm 0.7 \\
65.9 \pm 22.9\end{array}$ & $\begin{array}{l}\text { NS (p:0.5) } \\
\text { NS (p:0.1) }\end{array}$ \\
\hline 5 years & $\begin{array}{c}\mathrm{Cr}(\mathrm{mg} / \mathrm{dL}) \\
\operatorname{GFR}\left(\mathrm{mL} / \mathrm{min} / 1.73 \mathrm{~m}^{2}\right)\end{array}$ & $\begin{array}{c}1.5 \pm 0.7 \\
69.4 \pm 24.3\end{array}$ & $\begin{array}{c}1.5 \pm 0.7 \\
68.1 \pm 23.1\end{array}$ & $\begin{array}{l}\text { NS (p:0.8) } \\
\text { NS (p:0.5) }\end{array}$ \\
\hline 10 years & $\begin{array}{c}\operatorname{Cr}(\mathrm{mg} / \mathrm{dL}) \\
\operatorname{GFR}\left(\mathrm{mL} / \mathrm{min} / 1.73 \mathrm{~m}^{2}\right)\end{array}$ & $\begin{array}{c}1.9 \pm 8.6 \\
74.0 \pm 28.8\end{array}$ & $\begin{array}{c}1.4 \pm 0.8 \\
72.7 \pm 25.3\end{array}$ & $\begin{array}{l}\text { NS (p:0.4) } \\
\text { NS (p:0.6) }\end{array}$ \\
\hline
\end{tabular}

SRA - single renal artery; MRA - multiple renal artery; Cr - creatinine, GFR - glomerular filtration rate; NS - not significant

at 5 years varied from $70 \%$ to $88.6 \% .{ }^{8}$ Gawish et ap showed also no differences in graft survival between groups as well as Benedetti et al. ${ }^{10}$ The most recent meta-analysis ${ }^{6}$ showed higher 1-year graft survival (93.2\%) but lower 5-year graft sur- vival (81.4\%). However, this meta-analysis included studies that could have only 50 patients. So, that fact could introduce some heterogeneity. Nevertheless, like the meta-analysis, long-term outcomes were comparable between groups. 


\section{Recipients survival curve between groups}

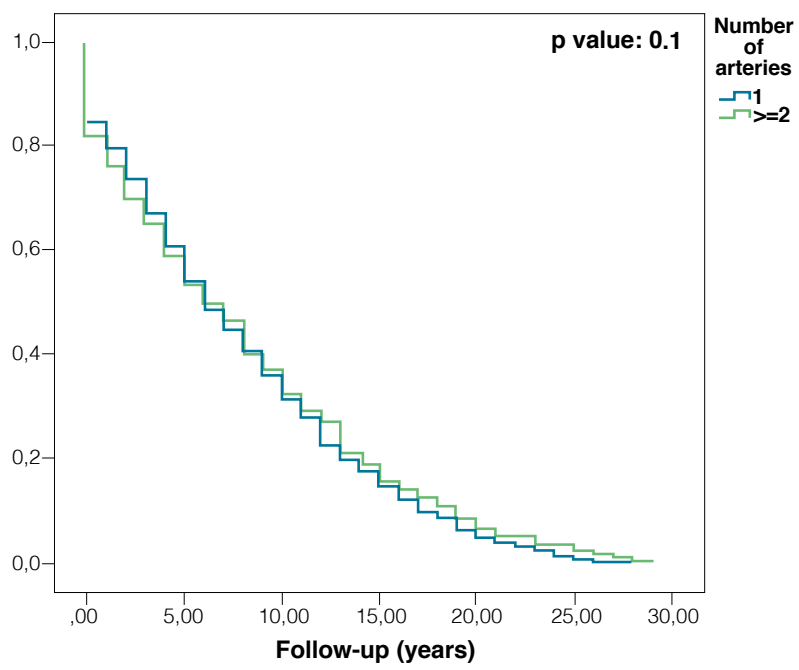

Figure 1: Comparison of recipient's survival curves between groups (Kaplan-Meier curve).

Table 7: Graft Survival time according to the type of arterial anastomosis adopted for multiple renal arteries graft anastomosis

\begin{tabular}{|l|c|c|}
\hline $\begin{array}{l}\text { Type of arterial } \\
\text { anastomosis }\end{array}$ & $\begin{array}{c}\text { Graft survival time } \\
\text { (years) }\end{array}$ & $\boldsymbol{p}$ value \\
\hline $\begin{array}{l}\text { Ex-vivo bench surgery } \\
\text { techniques }\end{array}$ & $7.7 \pm 7.2$ & NS (p:0.07) \\
\hline $\begin{array}{l}\text { In vivo sequential } \\
\text { anastomosis }\end{array}$ & $5.5 \pm 5.4$ & \\
\hline Mixed Techniques & $7.0 \pm 4.8$ & \\
\hline NS: not significant & \\
\hline
\end{tabular}

\section{Conclusion}

Multiple renal artery grafts were not a problem in our unit: despite needing a longer operative time, higher cold ischemia time and higher blood transfusions rate, the short and long-term outcomes were comparable between groups, allowing to be used safely and with results similar to single renal artery grafts.

\section{Ethical Disclosures}

Conflicts of Interest: The authors report no conflict of interest.

Funding Sources: No subsidies or grants contributed to this work.

Confidentiality of Data: The authors declare that they have followed the protocols of their work center on the publication of patient data.

Protection of Human and Animal Subjects: The authors declare that the procedures followed were in accordance with the regulations of the relevant clinical research ethics committee and with those of the Code of Ethics of the World Medical Association (Declaration of Helsinki)

Responsabilidades Éticas

Conflitos de Interesse: Os autores declaram a inexistência de conflitos de interesse na realização do presente trabalho.

Fontes de Financiamento: Não existiram fontes externas de financiamento para a realização deste artigo.

Proteção de Pessoas e Animais: Os autores declaram que os procedimentos seguidos estavam de acordo com os regulamentos estabelecidos pelos responsáveis da Comissão de Investigação Clínica e Ética e de acordo com a Declaração de Helsínquia da Associação Médica Mundial.

Confidencialidade dos Dados: Os autores declaram ter seguido os protocolos do seu centro de trabalho acerca da publicação dos dados de doentes.

${ }^{*}$ Corresponding author $/{ }^{*}$ Autor Correspondente:

João André Mendes Carvalho

Address: Rua Paulo Quintela, Lote 6, $7^{\circ}$ B, 3030-393 Coimbra

E-mail: joao.andre.mendes.carvalho@gmail.com

Recebido/Received: 2018-03-22

Aceite/Accepted: 2018-06-04

\section{REFERENCES}

1. Tonelli M, Wiebe N, Knoll G, Bello A, Browne S, Jadhav D, et al. Systematic review: kidney transplantation compared with dialysis in clinically relevant outcomes. Am J Transplant. 2011; 11: 2093-109. doi: 10.1111/j. 1600-6143.2011.03686.x

2. Novick AC, Magnusson M, Braun WE. Multiple-artery renal transplantation; emphasis on extracorporeal methods of donor arterial reconstruction. J Urol. 1979; $122: 731$.

3. Paragi PR, Klaassen Z, Fletcher HS, Tichauer M, Chamberlain RS, Wellen $\mathrm{JR}$, et al. Vascular constraints in laparoscopic renal allograft: comparative analysis of multiple and single renal arteries in 976 laparoscopic donor nephrectomies. World J Surg. 2011; 35: 2159-66. doi: 10.1007/s00268011-1168-6.

4. Hsu TH, Hsu THS, Su L, Trock BJ, Kavoussi LR. Impact of renal artery multiplicity on outcomes of renal donors and recipients in laparoscopic donor nephrectomy. Urology. 2003; 61:323-7.

5. Taghizadeh Afshari A, Mohammadi Fallah MR, Alizadeh M, Alizadeh M, Makhdoomi K, Rahimi E, et al. Outcome of kidney transplantation from living donors with multiple renal arteries versus single renal artery. Iran $J$ Kidney Dis. 2016;10:85-90

6. Zorgdrager M, Krikke C, Hofker SH, Leuvenink HG, Pol RA. Multiple renal arteries in kidney transplantation: a systematic review and meta-analysis. Ann Transplant. 2016;21:469-78.

7. Shapiro R, Simmons RL, Starzl TE. In: Shapiro R, editor. The transplant procedure: Renal transplantation. Stamford: Appleton \& Lange; 1997. p. 103-40.

8. Chabchoub K, Mhiri MN, Bahloul A, Fakhfakh S, Ben Hmida I, Hadj Slimen $\mathrm{M}$, et al. Does kidney transplantation with multiple arteries affect graft survival? Transplant Proc. 2011; 43:3423-5. doi: 10.1016/j.transproceed.2011.09.027.

9. Gawish AE, Donia F, Samhan M, Halim MA, Al-Mousawi M. Outcome of renal allografts with multiple arteries. Transplant Proc. 2007; 39:1116-7. doi: 10.1016/j.transproceed.2007.03.067

10. Benedetti E, Troppmann C, Gillingham K, Sutherland DE, Payne WD, Dunn DL,et al. Short- and long-term outcomes of kidney transplants with multiple renal arteries. Ann Surg. 1995; 221:406-414 